ReYnolds, D. M. (1954). J. gen. Microbiol. 11, 150-159.

\title{
Exocellular Chitinase from a Streptomyces sp.
}

\author{
By D. M. REYNOLDS \\ Department of Bacteriology, University of California, Davis, \\ California, U.S.A.
}

SUMMARY: A number of cultures of chitin-decomposing aerobic bacteria were isolated by the enrichment technique. Chitin decomposition was followed by measurement of loss of alkali-resistant insoluble substrate. Agitated submerged cultures secured a much more rapid breakdown of chitin than static cultures. The exocellular chitinase produced by a species of Streptomyces in agitated submerged culture was studied. The effects of $\mathrm{pH}$ value and substrate concentration on enzyme activity were examined and the results used to establish a chitinase assay in terms of reducingsugar production. The enzyme was an inducible one (adaptive). The enzyme was concentrated by ultrafiltration and lyophilization. The water-soluble reducing materials produced by the enzyme from chitin were identified as $\boldsymbol{N}$-acetylglucosamine and its corresponding disaccharide, $N$.N-diacetylchitobiose.

Chitin is a tough, pliable, widely distributed natural product resembling cellulose; its fibrous structure is derived from long unbranched chains of $N$-acetylglucosamine units connected by $\beta$-1,4-glucosidic linkages. Chitin is extremely resistant to chemical reagents; strong mineral acids are required to dissolve it.

Most of the published reports of microbial chitin decomposition are concerned with taxonomic and physiological studies rather than with the enzymic aspects of the process. Benecke (1905), the first worker to isolate and study a chitin-decomposing microbe, stated that his 'Bacillus chitinovorus' (a nonsporeformer) must possess a chitinase, but found no evidence of saccharidic products of chitinase activity. Folpmers (1921) suggested the existence of a water-soluble cell-free chitinase from the fact that his cultures of chitindecomposing Eubacteriales and actinomycetes produced clear zones in agar prepared with precipitated chitin. ZoBell \& Rittenberg (1938), from experiments with marine chitin-decomposing bacteria, suggested that chitin breakdown might result from either a cleavage of the glycosidic linkages or a splitting-off of the aminoacetyl group.

Karrer \& Hofmann (1929) used a snail gut enzyme to secure up to $85 \%$ conversion of chitin into $N$-acetylglucosamine, thus helping to establish that compound as the unit building block of the polysaccharide. No other enzymic breakdown products of chitin were identified. Grassmann \& Rubenbauer (1931) found that 'Luizym', a commercial product prepared from dried aqueous extracts of Aspergillus niger, split chitin into iodometrically detected reducing material of undetermined nature. Zechmeister, Tóth \& Balint (1938) and Zechmeister \& Tóth (1939) demonstrated that almond emulsin could be chromatographically separated into a $\beta$-glucosidase, an $\alpha$-galactosidase and a chitinase. The latter was further separated into a polysaccharidase and a 
second enzyme which preferentially hydrolysed the disaccharide building block of chitin, $N . N$-diacetylchitobiose. Jeuniaux $(1950,1951)$ found that chitindecomposing Eubacteriales from the snail gut and chitinoclastic soil actinomycetes produced exocellular chitinases.

\section{EXPERIMENTAL}

\section{Preparation of chitin substrate}

To secure a substrate for culture media, a supply of partly purified chitin was prepared according to the usual acid and alkali method, with the realization that a certain amount of denaturation was unavoidable. Shell fragments ( $<2 \mathrm{~mm}$.) of the Dungeness crab, Cancer magister, were held in a mechanically stirred suspension of dilute $\mathrm{HCl}$ and maintained at $\mathrm{pH} 2 \cdot 0-3 \cdot 0$ by repeated addition of acid for 3 days to remove calcium salts. After washing, the material was suspended in 4 vol. of $5 \%(\mathrm{w} / \mathrm{v}) \mathrm{KOH}$ and brought to $100^{\circ}$ in an autoclave for $3 \mathrm{hr}$., with intermittent mechanical stirring, to render the nonchitinous constituents soluble. The alkali treatment was repeated, the chitin washed and then dried at $70^{\circ}$. After grinding through a $0.5 \mathrm{~mm}$. mesh screen Wiley mill, the acid and alkali treatments were repeated, the oven-dried chitin Soxhlet extracted with $95 \%$ ethanol, and the dry powder ground in a ball mill. The yield was $17 \%$.

A purified lot of chitin for use as a substrate for the assay of chitinase was prepared by extracting the above material with $2.5 \%(\mathrm{v} / \mathrm{v})$ acetic acid to remove any chitosan possibly formed by the $\mathrm{KOH}$ treatment, followed by $95 \%$ ethanol extraction. The product was almost white in colour and had an ash content of $1.25 \%$. Microchemical analysis gave the following results : calculated-C, $47 \cdot 3 ; \mathrm{H}, 6 \cdot 4 ; \mathrm{N}, 6 \cdot 89 ;-\mathrm{COCH}_{3}, 22 \cdot 17 \%$; found-C, $43 \cdot 1 ; \mathrm{H}, 7 \cdot 0$; $\mathrm{N}, 6 \cdot 87 ;-\mathrm{COCH}_{3}, 19 \cdot 2 \%$.

Colloidal precipitated chitin was prepared roughly according to the procedure of Bucherer (1935) and preserved in the frozen state.

\section{Isolation and testing of chitin-decomposing bacteria}

Enrichment cultures were set up using a mineral salt medium $\left(\mathrm{K}_{\mathbf{2}} \mathrm{HPO}_{\mathbf{4}}\right.$, $0.7 \mathrm{~g}$; $\mathrm{KH}_{2} \mathrm{PO}_{4}, 0.3 \mathrm{~g}$.; $\mathrm{MgSO}_{4} .5 \mathrm{H}_{2} \mathrm{O}, 0.5 \mathrm{~g}$.; $\mathrm{FeSO}_{4} .7 \mathrm{H}_{2} \mathrm{O}, 0.01 \mathrm{~g}$.; $\mathrm{ZnSO}_{4}$, $0.001 \mathrm{~g}$.; distilled $\mathrm{H}_{2} \mathrm{O}, 1 \mathrm{l}$.; $\mathrm{pH}$ adjusted to 7.0) to which powdered chitin $(0.25 \%, w / v)$ was added as a sole source of $\mathrm{C}$ and $\mathrm{N}$. The medium was dispensed in $5 \mathrm{~mm}$. layers in Erlenmeyer flasks; separate flasks of each medium were inoculated with dilutions of eight garden and forest soils. The flasks were incubated both statically and on a rotary table shaker (New Brunswick Scientific Co.) which described a circle of $2.5 \mathrm{~cm}$. diam. and ran at 325 r.p.m. All culture incubation described in this paper was at $28^{\circ}$.

To isolate pure cultures of chitin-decomposing microbes, we plated out the above enrichments after 2 weeks on to neutral mineral salts agar containing sufficient colloidal precipitated chitin to render it cloudy. Bacteria were isolated and purified from $\mathbf{4 1}$ colonies which formed clear zones in the chitin. The above enrichment procedure, using chitin as a sole $\mathrm{C}$ and $\mathrm{N}$ source, 
admittedly selected against nutritionally fastidious chitin-decomposing microbes.

These 41 isolates were tested for ability to decompose chitin in agitated submerged culture, following approximately the method of Reese (1947) for aerobic cellulose decomposition studies. Portions $(250 \mathrm{mg}$.) of powdered chitin were weighed into $250 \mathrm{ml}$. Erlenmeyer flasks which were uniformly inoculated and incubated on the rotary shaker for 15 days. Sufficient $5 \mathrm{~N}-\mathrm{KOH}$ was then added to make the $\mathrm{KOH}$ concentration $0.5 \mathrm{~N}$, all growth submerged in the alkaline solution, and the flasks autoclaved at $121^{\circ}$ for $15 \mathrm{~min}$. The alkaliinsoluble residue was collected in a tared $30 \mathrm{ml}$. Selas semi-porous crucible (No. 3001), washed with water, and dried at $105^{\circ}$ for $16 \mathrm{hr}$. The cooled crucibles were weighed, ignited for $8 \mathrm{hr}$. at $650^{\circ}$, and reweighed for ash. An experiment with uninoculated flasks showed that $100 \pm 1 \%$ of the chitin was recovered by this method. The decomposition of organic matter was calculated as

$\%$ loss of organic matter $=\frac{[\text { post-alkali residue }]-[\text { culture ash] }}{\text { [original chitin, water-free }]-[\text { culture ash }]} \times 100$.

Since the bacteria formed a certain amount of alkali-resistant polysaccharide during growth, the actual percentage of chitin loss was always somewhat greater than indicated by the data.

When subjected to the above screening procedure, all of the zone-producing organisms showed some ability to decompose chitin in aerated submerged culture. The amount of chitin decomposed ranged between 10 and $97 \%$ of the starting material. In a number of cases, the amount of decomposition strikingly increased when yeast extract $(0.05 \%, w / v)$ was added to the medium, e.g. in one instance from 17 to $90 \%$ chitin loss over 15 days. The study of such nutritional aspects of chitin decomposition will be reported later. For the purpose of this investigation, in which a culture fluid with chitinase activity was sought, those cultures which could actively decompose chitin with that compound as a sole source of $\mathrm{C}$ and $\mathrm{N}$ were chosen for further study. The avoidance of complex organic media would render subsequent enzyme concentration and purification less difficult.

The speed of chitin breakdown with the three most active organisms in the above experiment (two Streptomyces spp. and a true bacterium) was ascertained by inoculating each organism into eight replicate flasks of the same medium, and removing pairs at intervals for alkali treatment. The results (Fig. 1) showed that a rapid chitin breakdown took place in submerged cultures of all three organisms. With static incubation of $5 \mathrm{~mm}$. deep layers of media, the amount of chitin breakdown after a month was only a small fraction of that secured with shaken flasks of these aerobic cultures in 5 days.

\section{Demonstration of a cell-free microbial chitinase}

The above data were used as a guide to harvesting identical submerged cultures of the three organisms for an examination for chitinase activity in the culture fluids. After 4 days' growth with the Streptomyces spp. (C-10 and C-14) and 8 days for the bacterium $(\mathrm{C}-25)$, the cell material was centrifuged 
off and the supernatants preserved by the addition of sufficient $1 \%(w / v)$ aqueous thiomersalate to produce a concentration of $0.01 \%(\mathrm{w} / \mathrm{v})$. The three solutions were each divided into equal parts which were adjusted, respectively, to $\mathrm{pH}$ 's $5 \cdot 0$ and $8 \cdot 0$.

A test for chitinase activity was made on these solutions by dispensing $50 \mathrm{mg}$. of the ball-milled highly purified chitin into $50 \mathrm{ml}$. Erlenmeyer flasks, adding $10 \mathrm{ml}$. of the cell-free fluid so as to produce a homogeneous suspension, and incubating the tinfoil-capped flasks for $48 \mathrm{hr}$. at $28^{\circ}$ on a slower (120 r.p.m.) table shaker running in a $2.5 \mathrm{~cm}$. diam. circle. Two controls were used: (i) flasks with the chitin in mineral salt solution; (ii) cell-free culture fluid without chitin; both controls contained thiomersalate. After incubation, the enzyme was inactivated by immersing the flasks for $5 \mathrm{~min}$. in a $100^{\circ}$ waterbath. Approximately $3 \mathrm{ml}$. of the flask suspensions were centrifuged at $18,000 \mathrm{~g}$ to remove residual chitin. Samples $(1.0 \mathrm{ml}$.) of the supernatant solutions were added to pairs of optically uniform Pyrex test tubes for reducingsugar assay by the dinitrosalicylic acid (DNS) method of Sumner \& Somers (1949) with the assay adjusted to the range $0.05-0.9 \mathrm{mg}$. glucose $/ \mathrm{ml}$. While both thiomersalate and phosphate salts can interfere with the DNS assay, this was not observed with the concentration of these substances present in the culture supernatants.

Table 1 summarizes the results' of the above test at $\mathrm{pH} 8.0$ for chitinase activity in the three organisms. The reducing-sugar found in flasks containing cell-free culture fluid was appreciably higher than that found in flasks containing fluid alone. In this and all subsequent experiments, the control flasks with cell-free fluid alone contained either no or at most a trace of reducing substance detectable by the procedure used. Likewise, the controls with chitin incubated with mineral salts solution were consistently negative for reducing sugars. Streptomyces sp. C-10 was selected for further enzyme work.

Table 1. Chitinase activity of cell-free culture fluids from three submerged cultures of chitin-decomposing bacteria

The figures represent averages of two flasks, each assayed in duplicate.

\begin{tabular}{clc} 
Culture & \multicolumn{1}{c}{ Solution assayed } & $\begin{array}{c}\text { Reducing-sugar } \\
\text { as glucose }(\mathrm{mg} . / \mathrm{ml} .)\end{array}$ \\
C-10 & Cell-free culture fluid & $<0.05$ \\
& Cell-free culture fluid + chitin & $0 \cdot 38$ \\
C-14 & Cell-free culture fluid & $<0 \cdot 05$ \\
& Cell-free culture fluid +chitin & $0 \cdot 26$ \\
C-25 & Cell-free culture fluid & $0 \cdot 06$ \\
& Cell-free culture fluid +chitin & $0 \cdot 15$ \\
None & Chitin + min. salt solution & $<0.05$
\end{tabular}

The observed chitinase activity was shown to be due to a cell-free enzyme (or enzymes) by filter sterilization of active centrifuged C-10 culture fluid with Morton Ultra Fine porosity sintered glass filters. Solutions so sterilized had a chitinase activity; a sterility test showed that no contamination took place before or during the period of enzyme activity. 


\section{Some properties of the enzyme}

$\mathrm{pH}$ range. With thiomersalate-treated cell-free culture fluid, enzyme solutions containing $\mathrm{m} / \mathbf{1 5}$ phosphate were prepared over the $\mathrm{pH}$ range $4.5-8 \cdot 3$; the range was extended to $\mathrm{pH} \mathrm{3.0} \mathrm{with} \mathrm{HCl}$. Additional buffer capacity to that of the phosphate was presumably provided by dissolved protein. Duplicate $10 \mathrm{ml}$. samples were assayed as above in $50 \mathrm{ml}$. flasks containing $30 \mathrm{mg}$. chitin incubated on the shaker at $28^{\circ}$ for $72 \mathrm{hr}$. The $\mathrm{pH}$ change in all but three of the nineteen different values of enzyme solution did not exceed 0.2 unit during the experiment; in three, it did not exceed 0.4 unit. The assay results (Fig. 2) indicated a $\mathrm{pH}$ optimum $c$. $\mathrm{pH} 6 \cdot 5-7 \cdot 5$, so that subsequent assays were run at $\mathrm{pH} \mathbf{7} \cdot \mathbf{0}$.

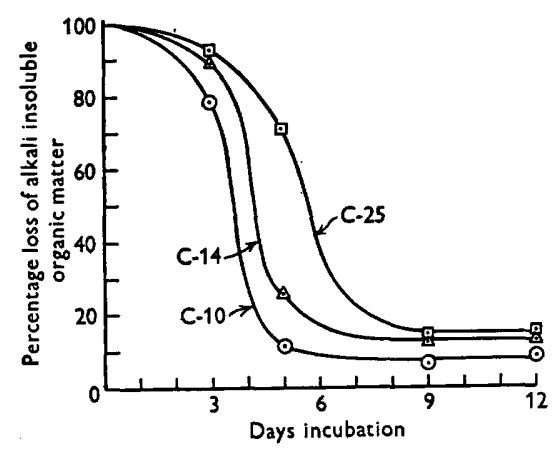

Fig. 1. Aerobic decomposition of chitin by three soil organisms in agitated submerged culture; C-10 and C-14. Streptomyces spp., C-25 a bacterium.

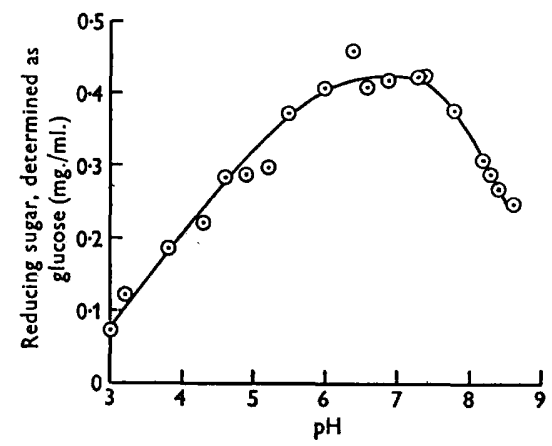

Fig. 2. The effect of $\mathrm{pH}$ on the activity of Streptomyces sp. C-10 chitinase.

Effect of substrate concentration. Chitin was distributed into pairs of Erlenmeyer flasks (75 mg./flask) and cell-free culture fluid added as follows: $10 \mathrm{ml} . / 50 \mathrm{ml}$. flask; $25 \mathrm{ml} . / 125 \mathrm{ml}$. flask; $50 \mathrm{ml} . / 250 \mathrm{ml}$. flask; $75 \mathrm{ml} . / 300 \mathrm{ml}$. flask. The flasks thus containing $7 \cdot 5,3 \cdot 0,1.5$ and $1.0 \mathrm{mg}$. chitin $/ \mathrm{ml}$. solution were then assayed with controls, using $28^{\circ}$ and $48 \mathrm{hr}$. incubation. In all the flasks, a large portion of the insoluble chitin was still visible after the assay. The results of the experiment (Fig. 3) led to the selection of $3 \mathrm{mg}$. chitin $/ \mathrm{ml}$. (actually $30 \mathrm{mg}$. $/ 10 \mathrm{ml}$.) for all subsequent assays. Since chitin is insoluble in water, one can readily establish that this substrate has not become exhausted during the course of a chitinase assay. Kinetic experiments have also shown that $3.0 \mathrm{mg}$. chitin $/ \mathrm{ml}$. is an adequate substrate concentration for assay work.

Improvements in the assay were later made when it was found that the enzyme had a temperature optimum at $37^{\circ}$. While at 20 and $28^{\circ}$ rotary agitation increased the amount of reducing-sugar production, at $37^{\circ}$ equal amounts of product were formed in both swirled and static flasks, thus rendering agitation unnecessary.

Enzyme induction by chitin. Streptomyces sp. C-10 was grown in the neutral mineral salt medium in agitated submerged culture with chitin $(0.5 \%, \mathrm{w} / \mathrm{v})$, $N$-acetylglucosamine $(0.3 \%, \mathrm{w} / \mathrm{v})$, or glucose $(0.1 \%$, w/v $)+$ asparagine $(0.05 \%$, 
w/v). The $N$-acetylglucosamine was sterilized by filtration. With the two monosaccharide media, growth of the actinomycete was moderate in amount; with the chitin medium, heavy. After given periods of time, the supernatants from pairs of duplicate flasks were assayed for chitinase activity. The results (Table 2) showed that only with the organisms grown in chitin was there evidence of formation of reducing-sugars from chitin by the cell-free culture fluids; the enzyme thus exhibited an induced (adaptive) behaviour.

Two $\beta$-1,4-linked polymers of glucose configuration sugars (cellulose and cellobiose) were not hydrolysed by the enzyme; it appears that if compounds of this type are to be cleaved by the enzyme, they must possess the aminoacetyl group.

Table 2. Effect of substrate on chitinase production by Streptomyces $s p$. C-10

\begin{tabular}{|c|c|c|c|c|}
\hline \multirow{3}{*}{$\begin{array}{l}\text { Compounds added } \\
\text { to basal mineral salt } \\
\text { medium }\end{array}$} & \multirow{3}{*}{$\begin{array}{l}\text { Age of } \\
\text { culture } \\
\text { (days) }\end{array}$} & \multicolumn{2}{|c|}{$\begin{array}{l}\text { Enzyme activity of cell- } \\
\text { free culture fluid }\end{array}$} & \multirow{3}{*}{$\begin{array}{l}\text { Reducing-sugar, } \\
\text { as glucose, } \\
\text { produced by } \\
\text { chitinase } \\
(\mathrm{mg} . / \mathrm{ml} .) \\
(2)-(1)\end{array}$} \\
\hline & & \multicolumn{2}{|c|}{$\begin{array}{l}\text { Alone With chitin } \\
\text { Reducing-sugar formed, } \\
\text { as glucose (mg./ml.) }\end{array}$} & \\
\hline & & (1) & (2) & \\
\hline Glucose + Asparagine & $\begin{array}{l}5 \\
6\end{array}$ & $\begin{array}{l}0 \cdot 77 \\
0 \cdot 35\end{array}$ & $\begin{array}{l}0.78 \\
0 \cdot 35\end{array}$ & $\begin{array}{l}0 \cdot 1 \\
0 \cdot 0\end{array}$ \\
\hline$N$-acetylglucosamine & $\begin{array}{l}\mathbf{3} \\
\mathbf{5}\end{array}$ & $\begin{array}{r}0.95 \\
<0.05\end{array}$ & $\begin{array}{r}0.95 \\
<0.05\end{array}$ & $\begin{array}{l}0 \cdot 0 \\
0 \cdot 0\end{array}$ \\
\hline Chitin & 5 & $<0.05$ & $0 \cdot 28$ & 0.28 \\
\hline
\end{tabular}

Stability of the enzyme. C-10 chitinase activity is very stable when the solutions are treated with $0.01 \%(\mathrm{w} / \mathrm{v})$ thiomersalate, brought to $\mathrm{pH} \mathbf{7}$ and stored at $4^{\circ}$. A sample of cell-free fluid stored under these conditions for 4 months showed only about $25 \%$ loss of activity.

Production of the enzyme in mass culture. To determine when maximum chitinase activity was reached, 2 l. Erlenmeyer flasks containing 1 l. of medium were inoculated at intervals over a period of 2 weeks with $50 \mathrm{ml}$. of a 3-day-old submerged C-10 culture and incubated on the shaker at 250 r.p.m. The flasks, ranging in age from 2 to 14 days, were simultaneously harvested and the culture supernatants assayed in the usual way. The results (Fig. 4) showed that peak chitinase activity was reached at 6 days incubation and fell off thereafter. The peak of activity coincided approximately with the time at which the last remaining chitin disappeared from the bottom of the flask.

A similar time study on chitinase formation was conducted with cultures in which the chitin neutral mineral salts medium received separately different nitrogenous supplements: Difco yeast extract $(0.2$ or $0.05 \%)$, asparagine $(0.1 \%)$, or a mixture of $\mathrm{NaNO}_{3}$ and $\mathrm{NH}_{4} \mathrm{NO}_{3}(0.07$ and $0.03 \%$, w/v). The basal chitin mineral salt medium gave higher peaks of chitinase activity than any of the media which received these nitrogenous supplements. Earlier experiments on chitin break-down by organisms which could grow with chitin as a sole source of carbon and nitrogen had shown that a number of these bacteria were much more effective in decomposing the polysaccharide when yeast extract was 
added to the medium, but Streptomyces sp. C-10 did not respond in this manner to yeast extract supplementation. It was therefore not surprising that this organism produced no increase in exocellular chitinase when yeast extract was added.

\section{Concentration of the enzyme by ultrafiltration and lyophilization}

A preliminary concentration of enzyme was made by means of nitrocellulose ultrafilters prepared after the procedure of Kabat \& Mayer (1948); a glass mantle surrounding the filter thimble allowed a greater degree of con-

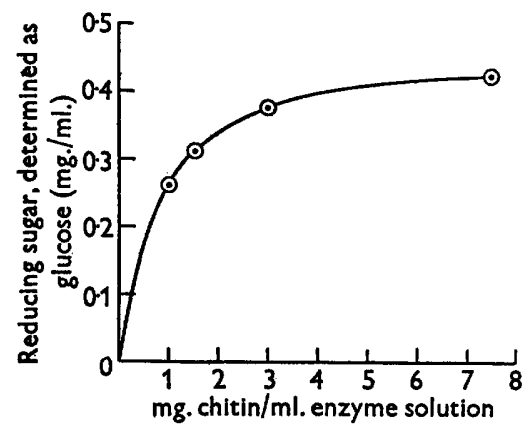

Fig. 3. The effect of substrate concentration on reducing sugar production by Streptomyces sp. C-10 chitinase.

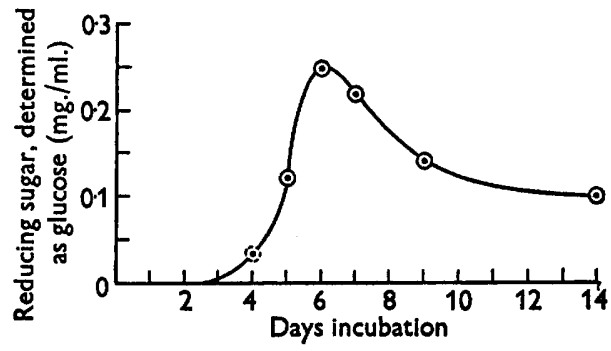

Fig. 4. Production of exocellular chitinase by Streptomyces sp. C-10 in agitated submerged culture with a chitin-mineral salts medium at different times of growth.

centration than in their technique. Active culture fluid (10 l.) was chilled to $5^{\circ}$, clarified with a Sharples supercentrifuge, treated with thiomersalate, adjusted to $\mathrm{pH} \mathbf{7 \cdot 0}$ and concentrated to $100 \mathrm{ml}$. (100-fold) with an ultrafilter prepared with a $5 \%(\mathrm{w} / \mathrm{v})$ cellulose nitrate solution. Controlled chitinase assays on the original solution $(0.32 \mathrm{mg}$. reducing-sugar $/ \mathrm{ml}$.), the solution passed by the ultrafilter $(<0.05 \mathrm{mg} . / \mathrm{ml}$.) and the solution retained by the ultrafilter $(14.0 \mathrm{mg} . / \mathrm{ml}$.) indicated that a marked concentration of the enzyme was secured by ultrafiltration. Further concentration of the ultrafilter-retained solution to the dry state without any loss of activity was made by freeze-drying.

A brown precipitate appearing on the surface of the ultrafilters was enzymically inactive and was subsequently separated from all ultrafilter concentrates by the Sorvall SS-1 centrifuge at 18,000 $\mathrm{g}$.

\section{Identity of chromatographically detectable enzyme products}

For chromatographic detection of reducing sugars, the phenylenediamine spray reagent of Chargaff, Levine \& Green (1948), modified by Mr F. Stadtman (1953, personal communication) by the substitution of oxalic acid for $\mathrm{HCl}$ was used; the reagent is prepared by dissolving $0.2 \%(\mathrm{w} / \mathrm{v})$ oxalic acid in approximately $95 \%$ ethanol. $o$-Phenylenediamine (instead of the meta isomer used by Chargaff et al.) was used, since the former on heating at $100^{\circ}$ for $15 \mathrm{~min}$. gave more distinguishable colours in daylight. A preliminary experiment showed that $\mathrm{N}$-acetylglucosamine was completely hydrolysed to glucosamine 
when it was dissolved at $5 \%(\mathrm{w} / \mathrm{v})$ in $\mathrm{N}-\mathrm{HCl}$ and heated to $100^{\circ}$ for $5 \mathrm{hr}$. in a sealed test tube.

A solution of the unknown reducing material produced by the enzyme was obtained by allowing $50 \mathrm{ml}$. active cell-free culture fluid to react with $500 \mathrm{mg}$. of highly purified ball-milled chitin in a $500 \mathrm{ml}$. Erlenmeyer flask at $28^{\circ}$ on the 120 r.p.m. shaker. After 7 days, a considerable amount of insoluble chitin remained in the flask. The suspension was heat inactivated, centrifuged and the supernatant passed through a small de-ionizing column filled with a mixture of cationic and anionic exchange resins. The solution was then concentrated to about $0.5 \mathrm{ml}$. (100-fold) by evaporation in vacuo at $70^{\circ}$. A similar control concentrate was made of an identical enzyme solution which had not accumulated reducing material by incubation with chitin. Whatman No. 1 filter-paper was set up with $10 \mu \mathrm{l}$. spots of the following materials: glucose $(1 \%, \mathrm{w} / \mathrm{v})$, glucosamine $: \mathrm{HCl}(5 \%, \mathrm{w} / \mathrm{v}), \mathrm{N}$-acetylglucosamine, both untreated and acid-hydrolysed $(5 \%, \mathrm{w} / \mathrm{v})$, the above enzyme concentrates, both control and chitin-reacted, and the latter concentrate acid-hydrolysed as above. Development of the descending $36 \mathrm{hr}$. phenol/water/ammonia chromatogram showed that the control enzyme preparation contained no detectable reducing compounds, whereas the concentrate of the enzyme previously reacted with chitin showed two spots, one with the same $\boldsymbol{R}_{F}$ and colour as secured with $\mathrm{N}$-acetylglucosamine and a second more rapidly moving unidentified compound. The identity of the slower enzyme product with $N$-acetylglucosamine was confirmed by the fact that the HCl-hydrolysed enzyme products gave a single spot with the same $\boldsymbol{R}_{F}$ and colour as glucosamine, which is under these conditions the hydrolysis product of $N$-acetylglucosamine.

Since the faster spot was also converted to glucosamine on acid hydrolysis, it seemed likely that it might be $N . N$-diacetylchitobiose. We secured $0.75 \mathrm{~g}$. of crystalline octa-acetylchitobiose which had been prepared from chitin after Bergmann, Zervas \& Silberkweit (1931). It had an m.p. of 306-308 (decomp.) and $[\alpha]_{\mathrm{D}}^{23}+56 \cdot 5^{\circ} \pm 0.4(1 \%, \mathrm{HOAc})$; these values are not in accord with those (m.p. $289^{\circ}$ and $[\alpha]_{\mathrm{D}}^{23}+50 \cdot 3^{\circ}$ ) secured by Bergmann et al., but are in agreement with those obtained for the same octa-acetate by Zechmeister \& Tóth (1931): $305^{\circ}$ and $[\alpha]_{\mathrm{D}}^{28}+55 \cdot 3^{\circ}$. The $\mathrm{O}$-acetyl groups were selectively hydrolysed from the octa-acetate by means of the Isbell barium methylate procedure described by Bates et al. (1942), yielding $N . N$-diacetylchitobiose.

The above described phenol/water/ammonia chromatogram was repeated with the addition of $N . N$-diacetylchitobiose and chitobiose octa-acetate. Both the $R_{F}$ values and the colours obtained with spots of the respective substances (Fig. 5) confirmed the earlier experiment and indicated that the previously unidentified enzymic product was $N$. $N$-diacetylchitobiose. The chromatogram was repeated with a collidine/water system with the same net results: two enzymic products were evident, with the $R_{F}$ values and spot colours of $N$-acetylglucosamine and $N . N$-diacetylchitobiose. With collidine/water the biose moved more slowly than the $N$-acetylglucosamine. In none of the chromatograms was there evidence that either glucosamine or glucose were produced from chitin by this enzyme. The product solution was examined with 
a two-dimensional chromatogram using the solvent system phenol/water/ ammonia followed by butanol/ethanol/water/ammonia $(45: 5: 49: 1)$. This experiment revealed no more than the two products already identified.

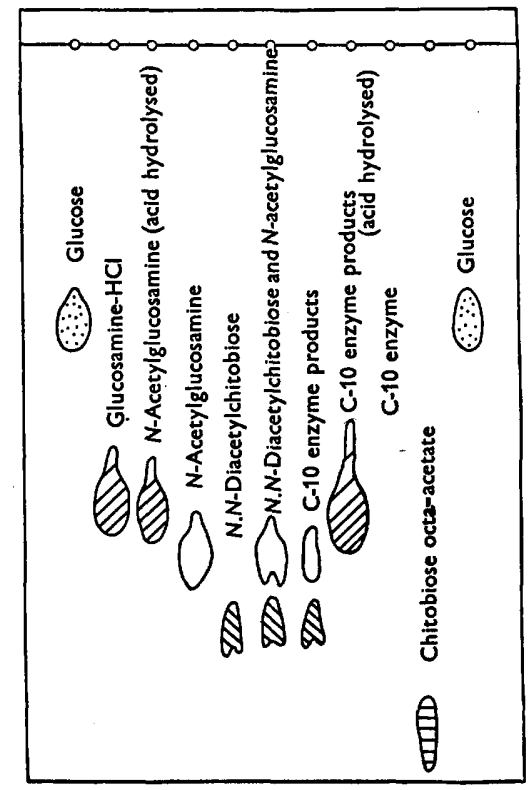

Fig. 5. Phenol/water/ammonia paper chromatogram of the water-soluble reducing products resulting from the hydrolysis of chitin by Streptomyces sp. C-10 chitinase. Spots developed by phenylenediamine and oxalic acid reagent. Colours of spots in daylight: $[\cdot]=$ blue; $[/]=$ brownish green; [ ]=reddish brown; $[\mid]=$ greenish brown; $[-]=$ greenish blue.

\section{DISCUSSION}

From our data it appears that enzymic chitin breakdown may follow the pattern of a number of other polysaccharides in that one or more enzymes degrade the compound to a biose stage which is then split by another enzyme. Supporting evidence of this lies in the fact that another similarly prepared chitinase product concentrate on chromatographic examination showed only a $N . N$-diacetylchitobiose spot; no monose was detected. Other polysaccharidases which accumulate bioses include the classical amylose $\rightarrow$ maltose phenomenon, the cellulose $\rightarrow$ cellobiose mechanism shown by Levinson, Mandels \& Reese (1951) and by Whistler \& Smart (1953), the xylan $\rightarrow$ xylobiose pathway (Sørenson, 1952) and the pectic acid $\rightarrow$ digalacturonic acid route of Dr A. L. Demain and Dr H. J. Phaff (1954, personal communication).

This work was supported by a grant-in-aid from the National Science Foundation, an agency of the United States Government. The author acknowledges with thanks the valuable technical assistance of Messrs C. E. Murphy and L. R. Berger. Thanks are also extended to Bioproducts, Ltd., of Warrenton, Oregon, for a generous supply of crushed crab shell, and to Dr D. Todd of the Worcester Foundation for Experi mental Biology, Shrewsbury, Mass., for his preparation of chitobiose octa-acetate.- 


\section{REFERENCES}

BAtes, F. et al. (1942). Polarimetry, Saccharimetry, and the Sugars. Washington: U.S. Government Printing Office.

BENECKE, W. (1905). Über Bacillus chitinovorus, einen Chitin zersetzenden Spaltpilz. Bot. Ztg (1. Abt.), 63, 227.

Bergmann, M., Zervas, L. \& Silberkweit, E. (1931). Über Chitin und Chitobiose. Ber. dtsch. chem. Ges. 64, 2436.

Bucherer, H. (1935). Über den mikrobiellen Chitinabbau. Zbl. Bakt. (2. Abt.), 93, 12.

Chargaff, E., Levine, C. \& Green, C. (1948). Techniques for the demonstration by chromatography of nitrogenous lipid constituents, sulfur-containing amino acids, and reducing sugars. J. biol. Chem. 175, 67.

Folpmers, T. (1921). De ontleding van chitine en zijn splitsingsproduct, het glucosamine, door bacteriën. Chem. Weekbl. 18, 249.

Grassmann, W. \& Rubenbauer, H. (1931). Über Zellulase und Hemizellulase mit besonderer Berücksichtigung ihrer therapeutischen Anwendung. Münch. med. Wschr. 78, 1817.

Jeuniaux, C. (1950). Production d'une exochitinase par des bactéries chitinolytiques isolées du contenu intestinal de l'escargot. Arch. int. Physiol. 58, 352.

Jeuniaux, C. (1951). Une méthode de dosage des chitinases. Arch. int. Physiol. 59, 242.

Kabat, E. A. \& MAYER, M. M. (1948). Experimental Immunochemistry. Springfield, Ill.: Chas. C. Thomas.

Karrer, P. \& Hofmann, A. (1929). Polysaccharide XXXIX. Über den enzymatischen Abbau von Chitin und Chitosan 1. Helv. Chim. Acta, 12, 616.

Levinson, H. S., Mandels, G. R. \& Reese, E. T. (1951). Products of enzymatic hydrolysis of cellulose and its derivatives. Arch. Biochem. Biophys. 31, 351.

REESE, E. T. (1947). On the effect of aeration and nutrition on cellulose decomposition by certain bacteria. J. Bact. 53, 389.

Sørensen, H. (1952). On the specificity and products of action of xylanase from Chaetomium globosum Kunze. Physiol. Plant. 5, 183.

Sumner, J. B. \& Somers, G. F. (1949). Laboratory Experiments in Biological Chemistry, 2nd ed. New York: Academic Press.

Whistler, R. L. \& Smart, C. L. (1953). Isolation of crystalline $d$-glucose and cellobiose from an enzymatic hydrolyzate of cellulose. J. Amer. Chem. Soc. 75, 1916.

Zechmeister, L. \& Tóth, G. (1931). Zur Kenntnis der Hydrolyse von Chitin mit Salzsäure (1. Mitteil.). Ber. dtsch. chem. Ges. 64, 2028.

Zechmeister, L. \& Tóth, G. (1939). Chromatographische Zerlegung der Chitinase. Naturwissenschaften, 27, 367.

Zechmeister, L., Tóth, G. \& Balint, M. (1938). Über die chromatographische Trennung einiger Enzyme des Emulsins. Enzymologia, 5, 302.

ZoBeli, C. E. \& RitTenberg, S. C. (1938). The occurrence and characteristics of chitinoclastic bacteria in the sea. J. Bact. 35, 275. 